Аналіз біокристалограмм дослідних зразків свідчить, щяо ЕКД є екологічно безпечною та не має загрози для стану довкілля або здоров'я та життя тварин і людей. При визначенні ОВП ЕКД встановлено, що продукт легко засвоюється, оскільки володіє біологічною сумісністю з організмом тварин. Встановлено доцільність використання технологічного процесу екструдування для зниження токсичності водоростей. До складу ЕКД водорості можна вводити у кількості до $15 \%$.

Представлені результати біологічних досліджень ЕКД в умовах іп vivo, які свідчать про високу біологічну ефективність використання водоростевої кормової добавки у складі комбікормів для молодняка сільськогосподарської птиці в кількості до 25 \%, оскільки підвищуються середньодобові прирости маси тіла щурів та зменшуються витрати комбікормів.

Ключові слова: екструдована кормова добавка з водоростями, біотестування, органічність, біокристалограмма, окисно-відновлювальний потенціал.

\title{
ЛІТЕРАТУРА
}

1. Крусір Г.В., Кіріяк А.В., Чернишова О.О. Екологічне маркування органічних комбікормів // Зернові продукти і комбікорми. 2015. T. 15, вип. 1. С. 17-20.

2. Show more Seaweeds for livestock diets: A review / Makkar H. et al. // Journal of Animal Feed Science and Technology. 2016. Vol. 212, No. 1. P. 1-17.

3. Seaweed as a protein source for mono-gastric livestock / Angell A. et al. // Trends in Food Science \& Technology. 2016. Vol. 54, No. 1. P. 74-84.

4. Rajauria G. Seaweeds: a sustainable feed source for livestock and aquaculture // Seaweed Sustainability. Food and NonFood Applications: book/ed. by Brijesh K. Tiwari and Declan J. Troy. Elsevier, 2015. Topic 15. P. 389-420.

5. Макаринська А.В. Технологічні способи переробки водоростей / Збірник тез доповідей 75 наукової конферениії викладачів академії. Одеса: МОН Украӥни, ОНАХТ, 2015. С. 28-29.

6. Макаринская А.В. Морские водоросли как компонент комбикормов // Зернові продукти і комбікорми. 2014. T. 14, Bbin. 4. C. 44-50.

7. Fleurence J., Levine I. Seaweed in Health and Disease Prevention. 1st Edition: book. Academic Press, $2016.476 \mathrm{p}$

8. Мардар М.Р., Крусір Г.В., Янівська А.І. Біотестування в оцінюванні безпечності зернових пластівиів // Зернові продукти і комбікорми. 2014. T. 14, вип. 3. С. 18-23.

9. Kahl J., Busscher, N. \& Meier-Ploeger, A. Ganzheitliche Untersuchungs methoden zur Erfassung und Prüfung der Qualität ökologischer Lebensmittel: Stand der Entwicklung und Validierung: projekttitel. Bonn: Geschäftsstelle Bundesprogramm Ökologischer Landbau in der Bundesanstalt für Landwirtschaft und Ernährung, 2003. 265 p.

10. Standardization of the Biocrystallization Method for Carrot Samples / Busscher N. et al. // Biological Agriculture and Horticulture, Academic Publishers Printed in Great Britain. 2010. Vol. 27, No. 1. P. 1-23.

11. Шульи М.А., Писаревский А.М., Полозова И.П. Окислительный потенџиал. Теория и практика : монография. Львов: Л, 1984. 168c.

12. Виноходов Д.О. Научные основы биотестирования с использованием инфузорий : дис. на получение науч. степени докт. біол. наук: 03.00.23: защита 16.03.2007/ науч. рук. Р. Санкт-Петербург: Санкт-Петербургский технологический институт, 2007. 270 c.

Надійила 14.12.2018. До друку 05.01.2019.

Рецензія 25.12.2018

Адреса для переписки:

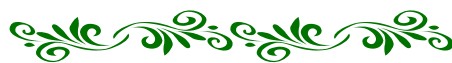

65039, Odessa, str. Kanatnaya 104, r. A 224.

UDK 634.4.084/27

(c) (i)

${ }^{1}$ O.Y. KARUNKYI, Dr. of Agricultural Sciences, Professor

${ }^{1}$ T.L. REZNIK, Postgraduate Student

${ }^{2}$ Ye.V. KULIDZHANOV,

${ }^{I}$ Odessa State Agrarian University, Odessa, Ukraine

${ }^{2}$ the Head of Affiliated State Centre "Ukrainian Institute of Soil Protection"

\section{CHLORELLA SUSPENSION AND ITS USAGE IN FINISHING PIGS' RATIONS}

Abstrakt

The animal husbandry cannot develop successfully without complete balanced feed and optimal forage supply.

This article deals with the chemical composition of chlorella suspension.

The ration is balanced with seaweeds as well as premixes, vitamins and bio supplement for the last decades. These seaweeds include chlorella - a representative of green microscopic algae.

The use of chlorella allows for multi-factor balancing of the diet in accordance with modern feeding standards, which increases the productive effect of feed and significantly increases the transformation of nutrients into livestock products. This is a relevant issue of modern animal husbandry.

The chlorella suspension was material for scientific research. It was made on the farm "In Samvel", Ovidiopol District.

According to the result of researches that took place on the farm "In Samvel", Biliayevka District, Odessa Oblast and SERF "Yuzhnyi" OSAGES NAAS, new data concerning chemical composition, the positive influence of investigated chlorella suspen- 
sion on the growth and development of finishing pigs as well as feed costs by $1 \mathrm{~kg}$ of growth were obtained. It has been established that the chemical composition of chlorella suspension takes a special place among all feed additives used in farm animals feeding.

It has been established that the additional use of chlorella suspension in the ration of finishing pigs of Large White breeds contribute to the increase of average daily gains by $121.9 \%$ against the control group in which chlorella suspensions was not given. Feed conversion to obtain $1 \mathrm{~kg}$ of pigs live weight gain in the control group was $5.1 \mathrm{~kg}$, in the experimental group - $4.2 \mathrm{~kg}$ and feed conversion index in the experimental group was higher by $21.4 \%$.

Thus the results of researches indicate the positive effect of investigated chlorella suspension on the growth and development of finishing pigs.

Due to the obtained results, we can state that the chemical composition of the suspension chlorella takes a special place among all feed additives used in farm animals feeding.

Chlorella has higher indicators of chemical composition, the amount of protein, vitamins and minerals in comparison with plant fodder and crops of agricultural production.

Keywords: chlorella suspension, chemical composition of chlorella, proteins, vitamins, minerals.

\section{Introduction}

According to numerous domestic and foreign studies and practice researches, the progress in the intensity of animals and poultry growth can be achieved only through the use of complete feed with high quality that allow to provide multi factorial balance of diets in accordance with modern feeding standards. In addition, the use of feed additives increases significantly the productive effect of feed and the transformation of nutrients into livestock products.

The use of fodder additives also helps to save feeds because the combination of biologically active substances provides the most complete digestion of nutrients in the feeds and it is confirmed scientifically.

The protein deficiency in rations and deficiency of biologically active substances including vitamins and mineral supplements are caused to search for nonconventional feed additives.

Additives are called non-conventional if they have been considered unsuitable for this purpose until now but the ration of animals can be provided with basic nutrients with the help of additives which are completely harmless or contain no harmful components in the unacceptable concentration.

Chlorella suspension is widely used in animal husbandry. In farm animals rations the use of a suspension gives positive results despite the fact that chlorella is not an important source of energy.

Chlorella has many advantages among feeds of plant origin and therefore it relates to green fodder. Chlorella can be used in a form of suspension giving a drink or moisturizing of feed in order to balance farm animals rations with a number of nutrients and biologically active substances.

The results of scientific researchers conducted by Ya.Ya.Struzh [4] have shown that the most efficient

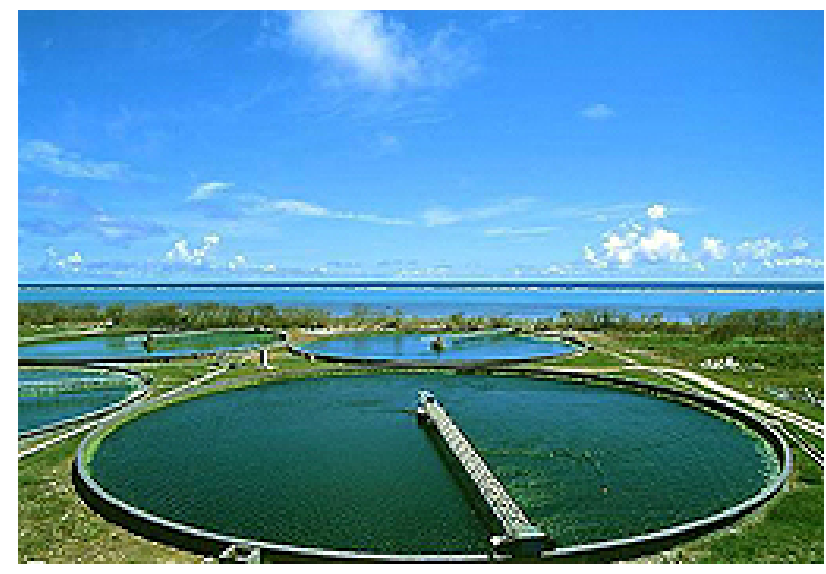

use of chlorella is in the form of suspension, because liquid chlorella has many advantages, namely, animals obtain biomass and biologically active substances through the solution.

Conducted researches by M.Ya. Salnikova [5] indicates that "the action of chlorella suspension is directed to enhance biological processes and the digestibility of gastric juice, to improve protein, vitamin and mineral metabolism in animals". As a result of these positive processes, we can observe the high energy of animal growth, the reduction in feed costs per unit of products and the improvement of general animals condition.

Therefore, the mechanism of chlorella suspension action on animals organism should be considered as a factor affecting on the whole body.

The development of scientific and practical bases for raising the productivity of animals is related with increased conversion of nutrients in feed to products. In addition, the use of biological and physiological indicators in animals is a relevant issue of modern animal husbandry.

Therefore, the system of researches was carried out to analyze chlorella suspension on the content of nutrients and biologically active substances and their suitability for feeding in farm animals diets.

\section{Material and methods of research}

The researches concerning chlorella chemical composition were carried out at the "Ukrainian Institute of Soil Protection" in "Chervonyi Khutir", Ovidiopol District, Odessa Oblast.

Scientific researches concerning chlorella suspension use (Chlorella Vulgaris) on fattening pigs were carried out at SERF "Yuzhnyi" OSAGES NAAS.

The researches were carried out on two groupsanalogues of young pigs Large White breed containing 12 heads in each (table 1). The equilibrium period was 15 days, after that animals of the second group were given chlorella suspension in the amount of $500 \mathrm{ml}$ per head a day. The first group was control and animals of this group were not given any supplements. The main period lasted 60 days.

The basic ration during equalization period included: barley- $0.7 \mathrm{~kg}$, maize $-0.5 \mathrm{~kg}$, wheat $-0.4 \mathrm{~kg}$, peas $-0.2 \mathrm{~kg}$, grass milling $-0.2 \mathrm{~kg}$, combined silage $1.4 \mathrm{~kg}$. Total nutrition of ration was 2.59 feed units and $209.3 \mathrm{~g}$ of digestible protein. According to the growth of experimental animals, the content of some feeds in the main ration increased due to the recommended, detailed 
rules. The basic ration for finishing pigs was used only in the control group and in the second experimental group, chlorine suspension was used and animals were given a drink according to the experimental scheme. Feeds counting and dosage of chlorella suspension were carried out daily and animals were weighted every month.

\section{Table 1. Scheme of experiment}

\begin{tabular}{|c|c|c|c|}
\hline \multirow[t]{2}{*}{ Group } & \multirow{2}{*}{$\begin{array}{l}\text { Number of } \\
\text { animals, } \\
\text { the heads }\end{array}$} & \multicolumn{2}{|c|}{ The nature of feeding } \\
\hline & & $\begin{array}{l}\text { Equal, } \\
15 \text { days }\end{array}$ & $\begin{array}{l}\text { Basic, } \\
60 \text { days }\end{array}$ \\
\hline I - control & 12 & $\mathrm{BD}$ & $\mathrm{BD}$ \\
\hline $\begin{array}{l}\text { II - } \\
\text { experimental }\end{array}$ & 12 & $\overline{\mathrm{BDD}}$ & $\begin{array}{l}\text { BD }+ \text { suspen- } \\
\text { sion of chlorell } \\
\text { (500 ml per } \\
\text { head per day) }\end{array}$ \\
\hline
\end{tabular}

\section{The results of research}

We can state that the chemical composition of chlorella suspension occupies a special place among all feed additives used in feeding farm animals due to the obtained results.

If we change the composition of the nutrient environment, it will lead to changes in the conditions of cultivation, because of this we can regulate the composition of chlorella suspension. This will enable you to enrich the animal products with the necessary biologically active substances.

The results of research are given in the Table 2 and they confirm the feed value of chlorella suspension.

As the purpose of the study is to substantiate the nutritional and chemical composition of chlorella suspension, we determined this indicator in the suspension and its moisture was $99.89 \%$.

The analysis of obtained materials shows that the chemical composition of chlorella suspension is approaching to the green mass of alfalfa. The value of this type of food is determined by the relatively high content of fat $0.09 \%$, protein $0.0092 \%$ and fiber $-0.19 \%$ in comparison with the green alfalfa food.

\section{Table 2. Chemical composition of suspension of} chlorella

\begin{tabular}{||l||l||c||c||}
\hline № & $\begin{array}{c}\text { Controlled } \\
\text { indicator }\end{array}$ & $\begin{array}{c}\text { Indicator } \\
\text { value } \\
\text { in fact }\end{array}$ & $\begin{array}{c}\text { The normative } \\
\text { document concerning } \\
\text { research method }\end{array}$ \\
\hline \hline 1 & 2 & 3 & 4 \\
\hline \hline 2 & Moisture, $\%$ & 99,89 & State St 27548-97 \\
\hline \hline 3 & Protein, $\%$ & 0,0092 & Uk State St 7169:2010 \\
\hline \hline 4 & Fat, $\%$ & 0,09 & State St 13496.15-97 \\
\hline \hline 5 & Ash, $\%$ & 0,052 & State St 26226-97 \\
\hline \hline 6 & Cellulose, $\%$ & 0,19 & State St 13496.2-91 \\
\hline \hline 7 & Calcium, $\%$ & 0,0012 & State St 26570-95 \\
\hline \hline 8 & Potassium, $\%$ & 0,0022 & State St 30504-97 \\
\hline \hline 9 & Phosphorus, $\%$ & 0,0012 & State St 26657-97 \\
\hline \hline
\end{tabular}

There are many very important mineral substances in the composition of chlorine suspension that are necessary for farm animals such as calcium, phosphorus, potassium, the presence of which was appropriate $0.0012-0.0022 \%$.

The researches have shown that during 60 days of giving a chlorella suspension, the best results were obtained in the second group, which was given a suspension of chlorella in an amount of $500 \mathrm{ml}$ per head a day (table 3 ).

Table 3. Fat indexes of pigs

\begin{tabular}{||l||c||c|}
\hline \multicolumn{1}{|c||}{ Indicator } & \multicolumn{2}{c|}{ Group } \\
\cline { 2 - 3 } & 1 & 2 \\
\hline \hline $\begin{array}{l}\text { Daily dose of chlorella suspension, } \\
\text { ml / head. }\end{array}$ & - & 500 \\
\hline \hline Live weight 1 head: start period, kg & 60 & 60 \\
\hline \hline Duration of the period, days & 60 & 60 \\
\hline \hline Growth of live weight: total, kg & 41 & 50 \\
\hline \hline average daily, kg & 683 & 833 \\
\hline \hline \pm control, $\%$ & & $+121,9$ \\
\hline \hline Feed costs per 1 kg growth, feed.unit & 5,1 & 4,2 \\
\hline \hline \pm to control, feed. unit & & $-0,9$ \\
\hline \hline \pm control, $\%$ & & $-21,4 \%$ \\
\hline \hline
\end{tabular}

The results obtained during the scientific and economic experiment showed that the most significant benefits of growth intensity were found in the second experimental group in which suspension of chlorella was given in a dose of $500 \mathrm{ml} / \mathrm{head}$. The average daily gain of pigs during the experiment was $833 \mathrm{~g}$ that is more significantly by $121.9 \%$ than in the control group in which chlorella suspensions was not given.

According to the data presented in the table 2, the conversion of feed to obtain $1 \mathrm{~kg}$ of live weight gain in pigs of control group was $5.1 \mathrm{~kg}$, in experimental - 4.2 $\mathrm{kg}$ and feed conversion index in the experimental group was already higher by $21.4 \%$.

When chlorella suspensions was used in the rations of experimental finishing animals, the increase of productivity indicators, feed conversion reduction and the increase of additional products as a result were observed.

\section{Conclusions}

Composition contains all nutrients and biologically active substances

In order to increase the productivity of finishing pigs and reduce feed costs, we recommend to use chlorella suspension in doses $0.5 \mathrm{ml} /$ head a day for two months.

Prospects for further research: to study the influence of chlorella suspension on morphological parameters of blood, digestibility of feed nutrients, evaluation of meat quality and economic indicators

\section{REFERENCES}

1. Bohdanov H. O. Aktual'ni pytannya hodivli s.-h. tvaryn / H. O. Bohdanov, D. O. Mel'nichuk, I. I. Ibatulin (ta inshi). Nauk. visnyk NAU. - 2004. - Vyp. 74. -s.11-24. 
2. Lymar V. O. Prohresyvni tekhnolohiyi v svynarstvi ta yikh perevahy/V. O. Lymar, V. M. Voloshchuk, I. V. Khat'ko (ta inshi) // SvynarstvoUkrayiny . - 2012. - №7. - s. 6-7.

3. Lemesheva M. M. Hodivlya sil's'kohospodars'koyi ptytsi / M. M. Lemesheva// Sumy.Slobozhanshchyna, 2003. - 148 s.

4. Struzh YA. YA. Ysledovanyya khlorelli v ratsyone svynomatok / YA. YA. Struzh// Kul'tyvyrovanye y prymenenye mykrovodorosley v narodnom khozyaystve: materyaly konf. - Tashkent: fan. UzSSR, 1984.- s. 43.

5. Sel'nykova M. YA. Khlorella - novyy vyd korma / M. YA. Sel'nykova. - M.: Kolos, 1977. -95s.

6. Branyikova I. Microalgae - nevelhiglyiffientstaroh producers / Branyikova I., Marsalkova B., Donche J // BiotechnolBioeng. 2011 Arp: 108 (4); 766-76. doi: 10/1002 / bit.23016. Epub 2010 Dec. 15.PMID: 2140425

О.Й. КАРУНСЬКИЙ, д-р с.-г. наук, професор Т.Л. РЕЗНІК, аспірант

С.В. КУЛІДЖАНОВ, директор

Одеська ф-ї ДУ «Інститут охорони трунтів України» Одеський державний аграрний університет, м.Одеса

\title{
СУСПЕНЗІЯ ХЛОРЕЛА ТА ІІЇ ВИКОРИСТАННЯ В РАЦІОНАХ СВИНЕЙ НА ВІДГОДІВЛІ
}

\begin{abstract}
Анотація
У статті розглядається питання щуодо хімічного складу суспензї хлорела. За останні десятиріччя поряд з преміксами, вітамінами, біодобавками кормовий раціон балансується за допомогою водорослів. До них відноситься хлорела - представник зелених мікроскопічних водоростів. Використання хлорели дозволяє забезпечити багатофакторне балансування рачіону відповідно до сучасних норм годівлі, завдяки чому підвищується продуктивна дія кормів, значно збільшується трансформація поживних речовин у продукиію тваринництва. Це являсться актуальною проблемою сучасного тваринництва.

Матеріалом досліджень була суспензія хлорели, щчо виробляє фермерське господарство «У Самвела» Біляївського району, Одеської області.

В результаті досліджень, які відбулися на базі фермерського господарства «У Самвела» Біляївського району Одеської області та ДПДГ «Южний» ОДСГДС НААН, одержано нові дані про хімічний склад , позитивний вплив досліджуваної суспензії хлорели на ріст і розвиток свиней на відгодівлі, затрати кормів на 1 кг приросту свиней. Встановлено, щзо за хімічним складом суспензія хлорели займає особливе місие серед усіх кормових добавок, щуо використовуються в годівлі сільськогосподарських тварин. В своєму складі суспензія хлорела містить всі поживні та біологічно активні речовини необхідні для обмінних процесів в організмі тварин.

Встановлено, щуо додаткове використання суспензї хлорела у раціоні свиней на відгодівлі м'ясної породи велика біла, сприяє підвищенню середньодобових приростів на 121,9\%, по відношенню до контрольної групи яка не отримувала суспензії хлорели. Конверсія корму на отримання 1 кг приросту живої маси у свинки контрольної групи склала 5,1 к2, у дослідній 4,2 к2, а коефіцієнт конверсії корму в дослідній групі був вище на 21,4\%. Таким чином, результати досліджень свідчать про позитивний вплив досліджуваної суспензії хлорела на ріст та розвиток свиней на відгодівлі.

Одержані результати дають можливість стверджувати, щзо за хімічним складом суспензія хлорели займає особливе місие серед усіх кормових добавок, щэо використовуються в годівлі сільськогосподарських тварин.

За хімічним складом, по кількості білку, вітамінів, набору мінеральних речовин хлорела має більші показники по відношенню до рослинних кормів і культур сільськогосподарського виробництва.

Ключові слова: суспензія хлорели, хімічний склад хлорели, білки, вітаміни, мінеральні речовини.

\section{ЛІТЕРАТУРА}

1. Богданов Г. О. Актуальні питання годівлі с.-г. тварин / Г. О. Богданов, Д. О. Мельнічук, І. І. Ібатулін (та інші). Наук. вісник НАУ. - 2004. - Bun. 74. -c.11-24.

2. Лимар В. О. Прогресивні технологї̈ в свинарстві та їх переваги / В. О. Лимар, В. М. Волошук, І. В. Хатько (та інші) // СвинарствоУкраӥни . - 2012. - №7. - с. 6-7.

3. Лемешева М. М. Годівля сільськогосподарської птиці / М. М. Лемешева// Суми. Слобожанщина, 2003. - 148 с.

4. Струж Я. Я. Иследования хлореллі в рационе свиноматок / Я. Я. Струж// Культивирование и применение микроводорослей в народном хозяйстве: материаль конф. - Ташкент: фан. УзССР, 1984.- с. 43.

5. Сельникова М. Я. Хлорелла - новый вид корма / М. Я. Сельникова. - М.: Колос, 1977. - 95с.

6. Branyikova I. Microalgae - nevelhiglyiffientstaroh producers /Branyikova I., Marsalkova B., Donche J // BiotechnolBioeng. 2011 Arp: 108(4); 766-76. doi: 10/1002/bit.23016. Epub 2010 Dec 15.PMID : 21404251
\end{abstract}

Надійила 06.12.2018. До друку 16.12.2018.

Рецензія 09.12.2018

Адреса для переписки:

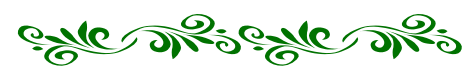

вул. Канатна, 112, м. Одеса, 65039 